\title{
PHD THESIS SUMMARY: \\ From the Lucasian revolution to DSGE models: an account of recent developments in macroeconomic modelling ${ }^{1}$
}

\author{
FRANCESCO SERGI
}

PhD in economics, March 2017

Université Paris 1 Panthéon-Sorbonne

In the last four decades, macroeconomic modelling practices underwent a deep transformation. My dissertation provides a history of this transformation, starting from Robert E. Lucas's work in the 1970s up to today's dynamic stochastic general equilibrium (DSGE) approach (Smets and Wouters, 2003). Working from a historical perspective, I suggest that the recent rise of DSGE models should be characterized as a shaky compromise between opposing views of modelling methodology-on the one hand, the real business cycle (RBC) view, on the other hand, the new Keynesian view. To justify this claim, my work provides an epistemological reconstruction of the recent history of macroeconomics, building from an analysis of the criteria defining the validity and the pertinence of a model.

My assumption is that recent macroeconomic modelling practices can be described by three distinctive methodological criteria: 1) the internal validity criterion (which establishes the consistency between models' assumptions and concepts and formalisms of a theory), 2) the external validity criterion (which establishes the consistency between the assumptions and results of a model and the real world, as well as the quantitative methods needed to assess such a consistency), and 3) the "hierarchization" criterion (which establishes the preference for internal over external validity, or vice versa). This epistemological analysis draws primarily from the literature about models in philosophy of science (especially Morgan and Morrison 1999).

My work aims to make four contributions to the history of recent macroeconomics. Firstly, to account for the rise of DSGE models without referring to the explanation provided by the macroeconomists

\footnotetext{
${ }^{1}$ Original title (the dissertation is in French): "De la révolution lucasienne aux modèles DSGE. Réflexions sur les développements récents de la modélisation macroéconomique".
} 
themselves, who tend to think that macroeconomics evolved through theoretical consensus and exogenous technical progress. By distancing itself from this perspective, my work draws attention to the disruptive character of methodological controversies and to the interdependence between theoretical activity and the development of statistical and econometric methods. Secondly, to overcome the existing divide between the history of macroeconomic theories (such as De Vroey, 2015) and the history of quantitative methods. Through its epistemological perspective, my work reconciles these two historiographies and specifies the basis for a comprehensive understanding of recent developments in macroeconomics. Thirdly, to put the accent on the external validity condition as the main controversial issue separating different views of macro-modelling methodology. Furthermore, I illustrate how the debate about external validity is closely related to the problem of causal explanation (such as recently discussed in Maki 2005 and Reiss 2012) and to the conditions for providing economic policy evaluation. Fourthly, to characterize the DSGE approach: although DSGE models are often presented as a "synthesis", or as a "consensus", they are better described as a shaky compromise between two opposing methodological visions.

Part I of the dissertation analyses Lucas's methodological view. Relying both on his published works (from the 1970s until today) and on archival material (correspondence, drafts), I emphasize the ambivalence of Lucas' vision of models, which suggest two incompatible definitions of external validity: on the one hand, 'black box' models, characterized by a-realistic assumptions; on the other hand, models as 'laboratories' for policy analysis, relying on causal analogies. Furthermore, I discuss how Lucas's view was implemented during the 1970 s by the new classical macroeconometric research program (Lucas and Sargent 1981), and emphasize the shortcomings of this approach in terms of methods and results.

Part II of the dissertation illustrates the competing views on models developed by RBC (Kydland and Prescott 1982) and new Keynesians (Mankiw and Romer 1991) during the 1980s and early 1990s. RBC modellers embraced Lucas's 'black box view' of models, emphasizing arealistic assumptions. As a result, they departed substantially from new classical economics by abandoning econometric methods and championing calibration. In contrast, new Keynesian economics 
emphasized the need for 'realistic' assumptions as an alternative to the RBC 'black box' models.

Part III of the dissertation analyses two debates, which illustrate the shift from the open conflict between RBC and new Keynesian views to a compromise-the DSGE approach-embodying these tensions. First, the famous Prescott (1986a, 1986b) and Summers (1986) controversy is reinterpreted within my methodological criteria to illustrate how methodological views on modelling were the underlying crucial issue of this debate. Inside the current DSGE approach, these two interpretations are still in conflict, as shown by the recent literature. In the final chapter of the dissertation, the on-going discussions on the vulnerability of DSGE models to the Lucas critique are shown to be a crucial example of this tension. I argue that two competing interpretations of the Lucas critique arose from opposing views on modelling methodology: whereas $\mathrm{RBC}$ conceived the Lucas critique as a theoretical proposition, pertaining to the internal validity criteria, new Keynesians rather interpreted the Lucas critique as an empirical proposition, pertaining to the external validity set of conditions. Today's DSGE modellers inherited these competing interpretations. Moreover, these competing interpretations result in alternative research paths that tend to destabilise the compromise about DSGE models.

\section{REFERENCES}

De Vroey, Michel. 2015. A history of modern macroeconomics from Keynes to Lucas and beyond. Cambridge: Cambridge University Press.

Kydland, Finn E., and Edward C. Prescott. 1982. Time to build and aggregate fluctuations. Econometrica, 50 (6): 1345-1370.

Lucas, Robert E., and Thomas J. Sargent (eds.). 1981. Rational expectations and econometric practice. London: George Allen and Unwin.

Mäki, Uskali. 2005. Models are experiments, experiments are models. Journal of Economic Methodology, 12 (2): 303-315.

Mankiw, N. Gregory, and David H. Romer (eds.). 1991. New Keynesian economics. Cambridge, MA: MIT Press.

Morgan, Mary S., and Margaret Morrison (eds.). 1999. Models as mediators: perspectives on natural and social science. Cambridge: Cambridge University Press.

Prescott, Edward C. 1986a. Theory ahead of business cycle measurement. Federal Reserve Bank of Minneapolis Quarterly Review, 10 (4): 9-22.

Prescott, Edward C. 1986b. Response to a skeptic. Federal Reserve Bank of Minneapolis Quarterly Review, 10 (4): 28-33.Reiss, Julian. 2012. The explanation paradox. Journal of Economic Methodology, 19 (1): 43-62. 
Smets, Frank, and Raf Wouters. 2003. An estimated dynamic stochastic general equilibrium model of the Euro area. Journal of the European Economic Association, 1 (5): 1123-1175.

Summers, Lawrence H. 1986. Some skeptical observations on real business cycle theory. Federal Reserve Bank of Minneapolis Quarterly Review, 10 (4): 23-27.

Francesco Sergi is teaching associate in the history of economic thought at the School of Economics, Finance and Management of the University of Bristol. He received his $\mathrm{PhD}$ in economics from the University of Paris 1 Panthéon-Sorbonne in March 2017. His PhD was supervised by JeanSébastien Lenfant (University of Lille 1) and Annie L. Cot (University of Paris 1 Panthéon-Sorbonne).

Contact e-mail: <francesco.sergi@bristol.ac.uk> 